Prepared for the U.S. Department of Energy

under Contract DE-AC05-76RL01830

\title{
Evaluating Effects of Stressors from Marine and Hydrokinetic Energy
}

\section{Fiscal Year 2012 Progress Report}

\section{Environmental Effects of Marine and Hydrokinetic Energy}

$\begin{array}{llll}\text { AE Copping } & \text { JA Ward } & \text { JL Elster } & \text { R Jepsen } \\ \text { KM Blake } & \text { JM Brandenberger } & \text { ME Jones } & \text { K Metzinger } \\ \text { LA Hanna } & \text { GA Gill } & \text { BE Watson } & \\ \text { CA Brandt } & \text { TJ Carlson } & \text { M Watkins } & \end{array}$

September 2012

Pacific Northwest

NATIONAL LABORATORY

Proudly Operated by Battelle Since 1965 


\title{
DISCLAIMER
}

This report was prepared as an account of work sponsored by an agency of the United States Government. Neither the United States Government nor any agency thereof, nor Battelle Memorial Institute, nor any of their employees, makes any warranty, express or implied, or assumes any legal liability or responsibility for the accuracy, completeness, or usefulness of any information, apparatus, product, or process disclosed, or represents that its use would not infringe privately owned rights. Reference herein to any specific commercial product, process, or service by trade name, trademark, manufacturer, or otherwise does not necessarily constitute or imply its endorsement, recommendation, or favoring by the United States Government or any agency thereof, or Battelle Memorial Institute. The views and opinions of authors expressed herein do not necessarily state or reflect those of the United States Government or any agency thereof.

\author{
PACIFIC NORTHWEST NATIONAL LABORATORY \\ operated by \\ BATTELLE \\ for the \\ UNITED STATES DEPARTMENT OF ENERGY \\ under Contract DE-AC05-76RL01830
}

Printed in the United States of America

Available to DOE and DOE contractors from the

Office of Scientific and Technical Information,

P.O. Box 62, Oak Ridge, TN 37831-0062;

ph: (865) 576-8401

fax: $(865) 576-5728$

email: reports@adonis.osti.gov

\author{
Available to the public from the National Technical Information Service, \\ U.S. Department of Commerce, 5285 Port Roy al Rd., Springfield, VA 22161 \\ ph: (800) 553-6847 \\ fax: $(703) 605-6900$ \\ email: orders@ntis.fedworld.gov \\ online ordering: http://www.ntis.gov/ordering.htm
}




\section{Evaluating Effects of Stressors from Marine and Hydrokinetic Energy}

\section{Fiscal Year 2012 Progress Report}

Environmental Effects of Marine and Hydrokinetic Energy

$\begin{array}{llll}\text { AE Copping } & \text { JA Ward } & \text { JL Elster } & \text { R Jepsen }^{1} \\ \text { KM Blake } & \text { JM Brandenberger } & \text { ME Jones } & \text { K Metzinger }^{1} \\ \text { LA Hanna } & \text { GA Gill } & \text { BE Watson } & \\ \text { CA Brandt } & \text { TJ Carlson } & \text { M Watkins } & \end{array}$

September 2012

Prepared for

the U.S. Department of Energy

under Contract DE-AC05-76RL01830

Pacific Northwest National Laboratory

Richland, Washington 99352

\footnotetext{
${ }^{1}$ Sandia National Laboratories, Albuquerque, New Mexico.
} 


\section{Summary}

Potential environmental effects of marine and hydrokinetic (MHK) energy development are not well understood, yet regulatory agencies are required to make decisions in spite of substantial uncertainty about environmental impacts and their long-term consequences. An understanding of risks associated with interactions between MHK installations and aquatic receptors, including animals, habitats, and ecosystems, can help define key uncertainties and focus regulatory actions and scientific studies on interactions of most concern. During FY 2012, Pacific Northwest National Laboratory (PNNL) continued to follow project developments on the two marine and hydrokinetic projects reviewed for Environmental Risk Evaluation System (ERES) screening analysis in FY 2011: a tidal project in the Gulf of Maine using Ocean Renewable Power Company TidGen ${ }^{\mathrm{TM}}$ turbines and a wave project planned for the coast of Oregon using Aquamarine Oyster surge devices.

The ERES project in FY 2012 also examined two stressor-receptor interactions previously identified through the screening process as being of high importance: 1) the toxicity effects of antifouling coatings on MHK devices on aquatic resources and 2) the risk of a physical strike encounter between an adult killer whale and an OpenHydro turbine blade.

The screening-level assessment of antifouling paints and coatings was conducted for two case studies: the Snohomish County Public Utility District No. 1 (SnoPUD) tidal turbine energy project in Admiralty Inlet, Puget Sound, Washington, and the Ocean Power Technologies (OPT) wave buoy project in Reedsport, Oregon. Results suggest minimal risk to aquatic biota from antifouling coatings used on MHK devices deployed in large estuaries or open ocean environments.

For the strike assessment of a Southern Resident Killer Whale (SRKW) encountering an OpenHydro tidal turbine blade, PNNL teamed with colleagues from Sandia National Laboratories (SNL) to carry out an analysis of the mechanics and biological consequences of different blade strike scenarios. Results of these analyses found the following: 1) a SRKW is not likely to experience significant tissue injury from impact by an OpenHydro turbine blade; and 2) if whale skin behaves similarly to the materials considered as surrogates for the upper dermal layers of whale skin, it would not be torn by an OpenHydro blade strike. The PNNL/SNL analyses could not provide insight into the potential for more subtle changes to SRKWs from an encounter with a turbine, such as changes in behavior, or inform turbine interactions for other whales or other turbines. These analyses were limited by the available time frame in which results were needed and focused on the mechanical response of whale tissues and bone to blade strike. PNNL proposes that analyses of additional turbine designs and interactions with other marine mammals that differ in size, body conformation, and mass be performed. 



\section{Project Overview}

Energy generated from the world's oceans and rivers offers the potential to make substantial contributions to the domestic and global renewable energy supply. The U.S. Department of Energy (DOE) Office of Energy Efficiency and Renewable Energy (EERE) Wind and Water Power Program supports the emerging marine and hydrokinetic (MHK) energy industry. As part of an emerging industry, MHK project developers face challenges related to siting, permitting, construction, and operation of pilot- and commercial-scale facilities, as well as the need to develop robust technologies, secure financing, and gain public acceptance.

Although potential effects of MHK energy generation on the aquatic environment have been catalogued (e.g., EERE $2009^{1}$ ), the conditions under which those effects could occur and their relative significance have not been firmly established. This lack of certainty affects siting and operations decisions, the regulatory process, and the level and nature of stakeholder concerns, all of which limit the pace and scale of MHK deployment.

To unravel and address the complexity of environmental issues associated with MHK energy, Pacific Northwest National Laboratory (PNNL) is developing a program of research and development that draws on the knowledge of the industry, regulators, and stakeholders and builds on investments made by the EERE Wind and Water Power Program. The PNNL program of research and development - together with complementary efforts of other national laboratories, national marine renewable energy centers, universities, and industry - supports DOE's market acceleration activities through focused research and development on environmental effects and siting issues.

Research areas addressed include

- Categorizing and evaluating effects of stressors - Information on the environmental risks from MHK devices, including data obtained from in situ testing and laboratory experiments (see other tasks below) will be compiled in a knowledge management system known as Tethys to facilitate the creation, annotation, and exchange of information on environmental effects of MHK technologies.

Tethys will support the Environmental Risk Evaluation System (ERES) that can be used by developers, regulators, and other stakeholders to assess relative risks associated with MHK technologies, site characteristics, waterbody characteristics, and receptors (i.e., habitat, marine mammals, and fish). Development of Tethys and the ERES will require focused input from various stakeholders to ensure accuracy and alignment with other needs.

- Effects on physical systems - Computational numerical modeling will be used to understand the effects of energy removal on water bodies from the short- and long-term operation of MHK devices and arrays. Initially, PNNL's three-dimensional coastal circulation and transport model of Puget Sound will be adapted to test and optimize simulated tidal technologies that resemble those currently in proposal, laboratory trial, or pilot study test stages. This task includes assessing changes to the physical environment (currents, waves, sediments, and water quality) and the potential effects of these changes on the aquatic food webs) resulting from operation of MHK devices at both pilot- and commercial-scale in river and ocean settings.

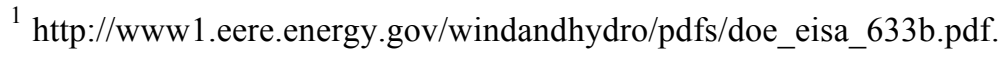


- Effects on aquatic organisms - Testing protocols and laboratory exposure experiments will be developed and implemented to evaluate the potential for adverse effects from operation of MHK devices in the aquatic environment. Initial studies will focus on electromagnetic field effects, noise associated with construction and operation of MHK devices, and assessment of the potential risk of physical interaction of aquatic organisms with devices. A variety of fish species and invertebrates will be used as test animals, chosen due to their proximity to and potential susceptibility to MHK devices.

- Permitting and planning - Structured stakeholder communication and outreach activities will provide critical information to the project team to support execution of other project tasks. Input from MHK technology and project developers, regulators and natural resource management agencies, environmental groups, and other stakeholder groups will be used to develop the user interface of Tethys, populate the database, define the risk attributes of the ERES, and communicate results of numerical modeling and laboratory studies of exposure of test animals to MHK stressors. This task will also include activities to promote consideration of renewable ocean energy in national and local Coastal and Marine Spatial Planning activities.

The team for the Environmental Effects of Marine and Hydrokinetic Energy Development project is made up of staff, faculty, and students from

- Pacific Northwest National Laboratory

- Marine Sciences Laboratory (Sequim and Seattle, Washington)

- Risk and Decision Sciences (Richland, Washington)

- Knowledge Systems (Richland, Washington)

- Oak Ridge National Laboratory (Oak Ridge, Tennessee)

- Sandia National Laboratories (Albuquerque, New Mexico; Carlsbad, California)

- Oregon State University, Northwest National Marine Renewable Energy Center (Newport, Oregon)

- University of Washington, Northwest National Marine Renewable Energy Center (Seattle, Washington)

- Pacific Energy Ventures (Portland, Oregon). 


\section{Acronyms and Abbreviations}

$\begin{array}{ll}\text { CT } & \text { computed tomography } \\ \text { DOE } & \text { U.S. Department of Energy } \\ \text { EERE } & \text { DOE Office of Energy Efficiency and Renewable Energy } \\ \text { EPA } & \text { U.S. Environmental Protection Agency } \\ \text { ERES } & \text { Environmental Risk Evaluation System } \\ \text { FERC } & \text { Federal Energy Regulatory Commission } \\ \text { kg } & \text { kilogram(s) } \\ \text { kPa } & \text { kilopascal(s) } \\ \text { kw } & \text { kilowatt(s) } \\ \text { L } & \text { liter(s) } \\ \mu \text { g/L } & \text { microgram(s) per liter } \\ \text { m } & \text { meter(s) } \\ \text { MHK } & \text { marine and hydrokinetic } \\ \text { MPa } & \text { megapascal(s) } \\ \text { MW } & \text { megawatt(s) } \\ \text { ng } & \text { nanogram(s) } \\ \text { NOAA Fisheries } & \text { National Oceanographic and Atmospheric Administration fisheries service } \\ \text { ORPC } & \text { Ocean Renewable Power Company } \\ \text { OPT } & \text { Ocean Power Technology } \\ \text { PNNL } & \text { Pacific Northwest National Laboratory } \\ \text { S-R } & \text { stressor-receptor } \\ \text { SnoPUD } & \text { Snohomish County Public Utility District No. 1 } \\ \text { SNL } & \text { Sandia National Laboratories } \\ \text { SRKW } & \text { Southern Resident killer whale } \\ \text { T\&E } & \text { threatened and endangered } \\ & \end{array}$





\section{Contents}

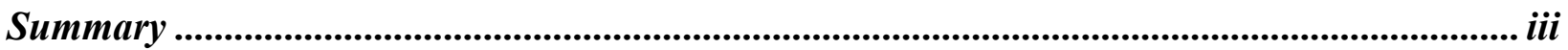

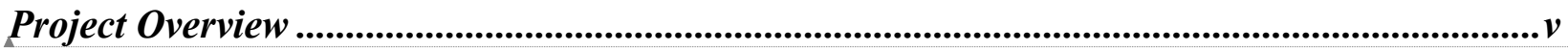

Acronyms and Abbreviations......................................................................................................... vii



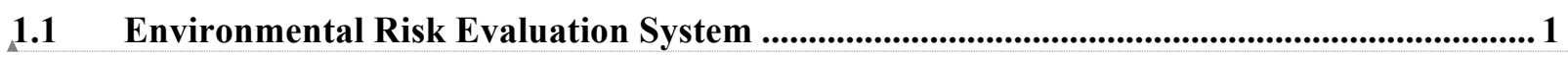

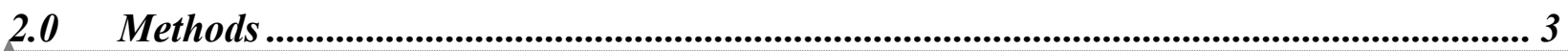

2.1 Tidal and Wave Case Study Analysis for Consequence ............ Error! Bookmark not defined

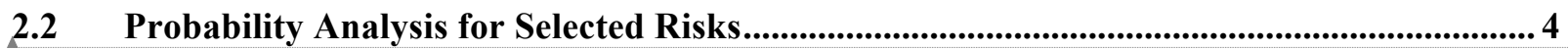

2.2.1 Toxicity Risk from Anti-Biofouling Coatings of MHK Devices ................................................. 6 ,

2.2.2 Assessment of a Strike of Adult Killer Whales by an OpenHydro Tidal Turbine Blade ......................

3.0 Results .....................................................................................Error! Bookmark not defined...

3.1 Screening Analysis Results for Tidal and Wave Case Studies.. Error! Bookmark not defined. 3.1.1 ERES Screening Analysis, Tidal Case Study - TidGen $^{\mathrm{TM}}$..................... Error! Bookmark not defined

3.1.2 ERES Screening Analysis, Wave Case Study - Oyster .......................... Error! Bookmark not defined,

3.2 Probability Analysis Results........................................................ Error! Bookmark not defined 3.2.1 Assessment of Toxicity from Anti-Biofouling Coatings on MHK Devices .......... Error! Bookmark not definedr

3.2.2 Risk of Encounter Between OpenHydro Tidal Turbine Blade and Killer Whale .................................. 12

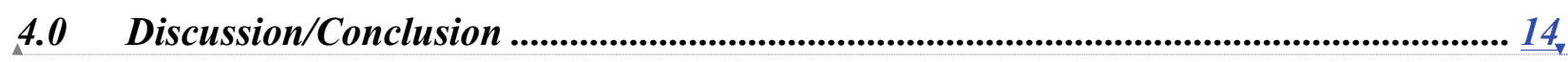

4.1 Screening Analysis for Tidal and Wave Case Studies ........................................................ 14.

4.2 Probability Analyses Undertaken in FY 2012 ......................................................................... 15,

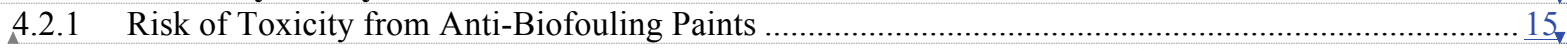

4.2.2 Assessment of Encounter Between OpenHydro Tidal Turbine Blades and Southern Resident Killer Whales 15 


\section{Figures}

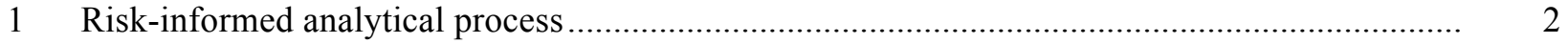

2 Hazard quotients for maximum, mean, and minimum toxicological benchmarks and exposure parameters for Puget Sound case study .................................................................Error! Book

3 Hazard quotients for maximum, mean, and minimum toxicological benchmarks and exposure parameters for Reedsport case study

\section{Tables}

1 Estimates of water volumes, water residence times, sedimentation rates, and sediment area for the Admiralty Inlet case study

Error! Bookmark

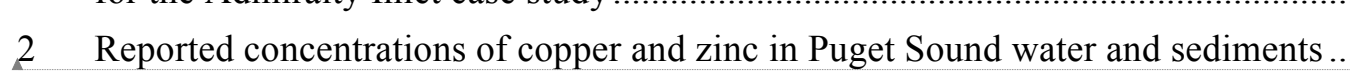
Error! Book And

3 Results of screening-level risk assessment for Admiralty Inlet case study Error! Bookr Unk

4 Background concentrations of copper and zinc in Oregon coastal sediments and Washington coastal waters

Fielc

5 Results of screening-level risk assessment for Reedsport case study Error! Book Andr

6 Level of certainty associated with each input to the engineering and biomechanical analyses 


\subsection{Introduction}

Pacific Northwest National Laboratory (PNNL) has been tasked by the U.S. Department of Energy (DOE) to investigate environmental effects from the deployment and operation of marine and hydrokinetic (MHK) devices, to provide information that will facilitate siting and permitting processes, and to recommend the most pertinent and useful research that supports those priorities.

A key step in setting regulatory and research priorities is the assignment of risk to interactions between MHK installations and aquatic receptors, including animals, habitats, and ecosystem processes in the marine and fresh waters where MHK development is feasible. Risk is defined as the likelihood of a prescribed adverse outcome from an action or set of actions. Risk assessment is the process of evaluating scientific information to estimate the probability of occurrence of the action and the severity of the effect (Suter 1993; U.S. Environmental Protection Agency [EPA] 2011). PNNL developed the Environmental Risk Evaluation System (ERES) to help define and assess the environmental risks arising from these new renewable energy installations.

\subsection{Environmental Risk Evaluation System}

The Environmental Risk Evaluation System (ERES) is a process PNNL developed to address the environmental risks associated with marine and hydrokinetic energy (MHK) devices in a context of environmental and regulatory uncertainties. Because the technology is new, the environmental impacts of MHK devices are not well known and the federal, state, and local regulatory oversight is unclear. Traditional methods of standardized risk assessment that require large known data sets are not well-suited to assess or set priorities for MHK, when hard scientific data is largely unavailable. The purpose of ERES is to provide regulators, decision-makers, and stakeholders an adaptive means to assess their tolerance toward risk, set priorities for research activities, and compare the costs and benefits of different MHK installation options both now, when uncertainties are high, and in the future, as more hard data on actual environmental effects becomes available.

ERES accomplishes this by evaluating all possible scenarios that could lead to adverse environmental impacts, from episodic scenarios such as a collision of a vessel with a MHK device, to chronic scenarios such as toxicity due to low-level chemical releases from anti-fouling paints or coatings. Between these two extremes, there are intermittent events, such as encounters between fish and rotating turbine blades. A key feature of understanding risk is describing the uncertainty associated with the occurrence of an episodic, intermittent, or chronic event, as well as the uncertainty of the resulting consequences.

Figure 1 shows the risk assessment process developed by PNNL. The initial steps in the process consist of a case selection process (blue box) and screening analysis based on environmental consequence (green box). Subsequent steps in the process include the refinement of risk characteristics through probability modeling (purple box) and communicating the findings for the development of monitoring and mitigation plans (red box). 


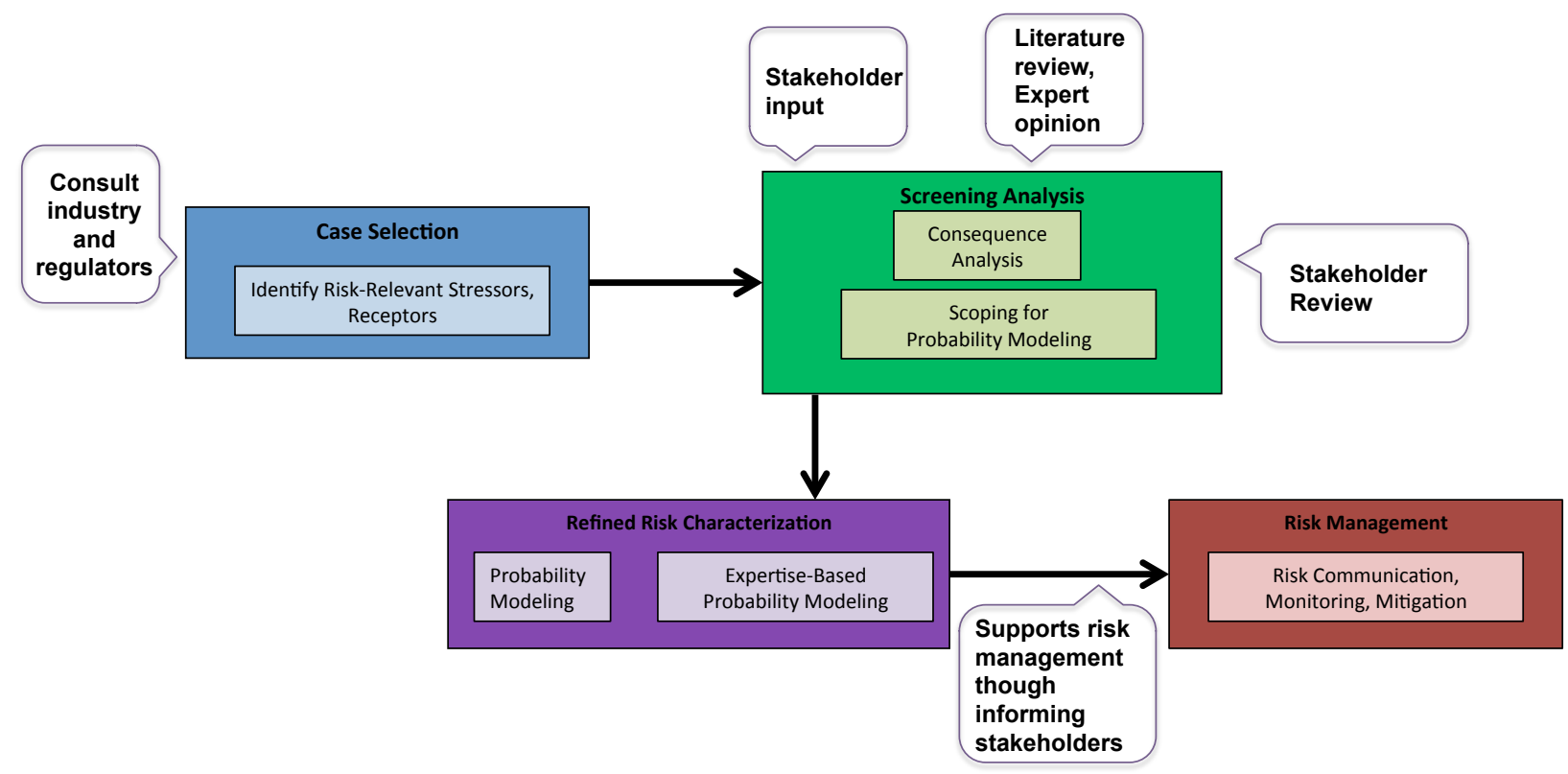

Figure 1. Risk-informed analytical process.

The process begins by selecting MHK cases of national interest for the ERES process (blue box). In FY 2010 and FY 2011, a diverse set of cases was selected from real MHK projects expected to be deployed within 2 years, to provide an integrated profile of the collective risk posed by a specific MHK system deployed in a specific body of water. In FY 2010, three cases were chosen for analysis: one tidal energy case (Snohomish County Public Utility District No. 1 [SnoPUD] in Admiralty Inlet, Puget Sound, Washington), one wave energy case (Ocean Power Technology [OPT] installation off Reedsport, Oregon), and one river installation (Free Flow Power [FFP] in the Mississippi River, Louisiana). In FY 2011, two additional cases were chosen for analysis: a second tidal energy case (Ocean Renewable Power Company [ORPC] in Cobscook Bay, Maine) and a second wave case (Aquamarine Power Ltd., Oyster wave energy converter [Oyster] off the Oregon coast).

For each case selected, scientific literature and reports were reviewed on each MHK technology and the specific aquatic animals, habitats, and ecosystem where the technology is intended to be deployed. A list of risk-relevant environmental stressors (e.g., spinning turbine blades, noise, chemical leaching) was developed, and possible environmental receptors (e.g., marine mammals, fish, birds, nearfield habitats) were identified.

Following case selection, the ERES process consists of a screening analysis for environmental consequence (Figure 1, green box), which involves determining the potential effects for the highestpriority interactions between the stressors and the chosen receptors from the case selection process. Each stressor-receptor ( $\mathrm{S}-\mathrm{R})$ interaction is ranked using 14 biophysical risk factors (or biological imperatives) to determine the vulnerability of the receptor to the stressor. A second set of risk factors, regulatory risk factors, is then applied to the $\mathrm{S}-\mathrm{R}$ pairs to create a new ranking of $\mathrm{S}-\mathrm{R}$ interactions that prioritizes interactions having high regulatory risk. Details on the methods for environmental consequence and the results from each of the five cases can be found in two previously published ERES project reports: Preliminary Screening Analysis for the Environmental Risk Evaluation System (Anderson et al. 2010) and Screening Analysis for the Environmental Risk Evaluation System (Copping et al. 2011). 
Once environmental consequences have been analyzed, the screening analysis proceeds to scoping for probability modeling (Figure 1, second light-green box). Refined characterization of priority risks identified through consequence analysis will be further evaluated (purple box) through probability modeling (first light purple box) in cases for which environmental data are available and expertise-based evaluation (second light purple box) in cases for which data are not yet available. Probability modeling will be preferentially conducted on top-ranked S-R interactions that appear to be most highly affected by the probability of occurrence (i.e., most probability-dependent interactions).

In FY 2012, the two cases that were screened for consequence analysis in FY 2011 were submitted to the developers for expertise-based evaluation. PNNL also conducted probability analyses for two S-R interactions for which sufficient data exist: 1) toxicity from anti-biofouling paints leaching into the marine environment and 2) a probability analysis focused on the physical strike encounter between a tidal turbine blade and a Southern Resident Killer Whale (SRKW), Orcinus orca.

With this report, the initial stages of ERES framework development are completed. Until many more data are available to replace the professional judgment used to rank consequences of S-R interactions for specific cases, the focus in risk assessment for MHK development will be on determining risk for specific interactions, such as the two interactions documented here.

This report discusses the progress made in the consequence analysis (expertise-based evaluation) conducted in FY 2012 for the wave and tidal energy cases reviewed in FY 2011. The report also details the results of two probability analyses performed in FY 2012. The methods used to conduct the screening analysis and initial risk modeling are detailed in Section 2. Results of the consequence analysis and probability modeling efforts are presented in Section 3. The outcomes and conclusions for the FY 2012 project activities are presented in Section 4. References cited are listed in Section 5.

\subsection{Tidal and Wave Case Study Analysis for Consequence}

The ERES consequence analysis consists of three steps: 1) identification and description of the case study; 2) identification of the risk-relevant stressors and receptors and description of impact scenarios; and 3) ranking of highest-priority risks (biophysical and regulatory) for each case, taking consequence into account. In FY 2011, two wave and tidal cases were analyzed for consequence through review of the scientific literature and reports and with input from a number of subject matter experts:

- Tidal Case Study - The technology developer Ocean Renewable Power Company (ORPC) is pursuing development of a 1.2-MW pilot project using its TidGen ${ }^{\mathrm{TM}}$ Power System in Cobscook Bay, Maine. The case is described as a hydrokinetic system mounted near the seafloor employing crossflow turbines to drive a magnet generator set between the turbines on a common driveshaft, designed to rotate in one direction regardless of the tidal flow direction. At this site, federally listed fish species (Gulf of Maine Distinct Population Segment of Atlantic salmon and Atlantic sturgeon) are key receptors of concern. Other receptors include diving birds, marine mammals, and nearshore habitat.

- Wave Case Study - The technology developer Aquamarine Power Ltd. is pursuing development of a project using its Oyster wave energy converter off the Oregon coast in the service areas of Central Lincoln People's Utility District and/or Tillamook People's Utility District. The case is described as 
an oscillating wave surge pump deployed in water depths between 24 and 48 feet, designed to capture energy from nearshore waves. Protected nearshore marine mammals (Steller sea lions, sea otters), endangered fish (Chinook salmon and green sturgeon), endangered diving birds (marbled murrelets), and sediment distribution are key receptors of concern.

To further gauge the validity of the ERES approach in FY 2012, these two cases were presented to the respective developers for peer review and comment. Section 2.1 provides a summary of the consequence analysis for these two FY 2011 case studies, a description of communications held with the developer in FY 2012, and an update on the progress of each project.

\subsection{Screening Analysis Results for Tidal and Wave Case Studies}

This section provides a summary of the findings of the ERES consequence analysis for the tidal case study (TidGen ${ }^{\mathrm{TM}}$ ) and the wave case study (Oyster), the expert elicitation conducted in FY 2012, and an update on the development of each project in FY 2012.

\subsubsection{ERES Screening Analysis, Tidal Case Study - TidGen ${ }^{\mathrm{TM}}$}

For the ORPC TidGen ${ }^{\mathrm{TM}}$ tidal case study, the biophysical risk analysis shows that interactions with the dynamic physical presence (i.e., blade strike) with marine mammals, diving birds, and threatened or endangered (T\&E) fish are relatively the highest concern for the project, along with effects of the tidal turbine to the far-field environment (including effects stemming from an accident or disaster, change in flow regime, or energy removal from the system). All of these potential consequences have a high degree of uncertainty and are issues requiring additional scientific study. In addition, the determination of the highest risk does not factor in how likely the event is to occur. After regulatory risk factors were applied, the highest-ranked issues narrow to include the impact of the device dynamic physical presence with threatened or endangered fish, followed by other environmental stressors on threatened or endangered fish. This second layering underscores that at this point in time, project developer OPRC must address the potential interactions of the TidGen ${ }^{\mathrm{TM}}$ device on threatened or endangered fish species in the deployment area in order to satisfy the legal mandates imposed on environmental regulators in the permitting process. The permitting pathway that ORPC is following in the Gulf of Maine (Cobscook Bay) is underscored by the finding of this consequence analysis. The results of the case study were shared with ORPC staff and the outcomes discussed to verify their fit with permitting requirements in Cobscook Bay, as specified in the FERC license granted to the company.

In FY 2012, ORPC obtained a hydrokinetic pilot project license from the Federal Energy Regulatory Commission (FERC) on February 27, 2012, for the Cobscook Bay Tidal Energy Project (FERC 2012). The goal of the pilot process is to "allow developers to test new hydrokinetic technologies, to determine appropriate sites for these technologies, and to confirm the technology's environmental and other effects without compromising [FERC] oversight of the project or limiting agency and stakeholder input" (FERC 2012, p. 1). Environmental protection, mitigation, and enhancement measures required as part of the FERC pilot license include the following:

1. restrictions on pile driving activities, including a limited pile driving season

2. an Acoustic Monitoring Plan

3. a Benthic and Biofouling Monitoring Plan 
4. a Fisheries and Marine Life Interaction Monitoring Plan

5. a Hydraulic Monitoring Plan

6. a Marine Mammal Monitoring Plan

7. adherence to Bald Eagle Management Guidelines and Bird Monitoring Plan (FERC 2012, pp. 31-35).

These monitoring plans and environmental protection and mitigation measures mirror and address the interactions of high concern PNNL identified in the ERES consequence screening process.

ORPC installed its commercial power system on the bottom of Cobscook Bay in summer 2012, which started generating power for the grid in September 2012 (Portland Press Herald 2012). It is anticipated that this initial system will run and be monitored for 1 year, and additional power systems up to $5 \mathrm{MW}$ will be added over the next 3 years.

\subsubsection{ERES Screening Analysis, Wave Case Study - Oyster}

For the wave case study, the biophysical risk analysis shows the potential consequences to the physical environment (changes in flow regime, energy removal, and the impact of an accident or disaster) as the highest relative risk, followed by the potential consequence of the dynamic physical presence of the device or an accident/disaster on T\&E species of nearshore marine mammals, birds, reptiles, and fish. Effects on the physical environment rank particularly high in this wave case study because of the uncertainties about the siting of this nearshore project on a predominantly soft bottom substrate. Threatened and endangered receptors also rank high on the biophysical risk analysis because of the impact that a potential consequence may have on species with small population sizes. The $\mathrm{S}-\mathrm{R}$ pairs in these top relative biophysical tiers are all issues needing additional scientific study. Combining biophysical and regulatory risk factors, the highest relative ranks include the potential consequence of the dynamic physical presence or an accident/disaster on T\&E species of nearshore marine mammals, birds, reptiles, and fish. This second analysis places highest priority for Aquamarine to first address the potential impacts of the wave device on all T\&E species in the deployment region in order to advance the deployment of a device in Oregon waters. The MHK projects represented by each case require that the probability of occurrence of the potential risk be evaluated, including the real potential for T\&E species to occur in the vicinity of the devices. The need to evaluate the presence of animals of concern is perhaps most acute in the Oyster case. Results from European deployments of the Oyster show no signs of animals being directly affected by the devices; potential deployment in the United States may hinge on rapidly identifying the presence of T\&E animals at risk. Although the nature of this analysis does not assign high rank to changes in sediment transport and soft bottom habitat from the action of the Oyster, it is likely that if T\&E species are not found to frequent the depths and location of the project, movement of sediment due to device operation will emerge as the most likely concern for regulators and stakeholders.

The results of the ERES analysis were shared with representatives of Aquamarine in Oregon; unfortunately the company determined soon thereafter that wave power development with the Oyster was not feasible in Oregon and ceased progress on the project.

In November 2011, Aquamarine Power pulled its office out of Oregon, saying that a lack of regulatory certainty over the ability to acquire seabed leases pending completion of the Oregon Territorial 
Sea Plan process has made it impossible to continue investing resources in Oregon. ${ }^{1}$ The company has consolidated its U.S. operations in a California office and is continuing to explore sites on the U.S. West Coast in California and Washington, stating that it hopes to return to Oregon at some point. ${ }^{2}$. A number of locations for the Oyster wave energy device are also being explored in Scotland and Ireland. In June 2012, Aquamarine Power commenced operational testing of its second-generation Oyster 800 wave energy machine at the European Marine Energy Centre (EMEC). ${ }^{3}$

\subsection{Probability Analysis for Selected Risks}

The refined characterization of two priority risks highlighted through the ERES consequence analysis were further evaluated through probability modeling on top-ranked S-R interactions that appear to be most highly affected by the probability of occurrence. The two interactions chosen for probability modeling were: 1) toxicity from anti-biofouling paints leaching into the marine environment and 2) a probability analysis focused on the physical strike encounter between a tidal turbine blade and a Southern Resident Killer Whale (SRKW), Orcinus orca. This section provides an overview of each probability analysis, describing the methodology and results of each case.

\subsection{Toxicity Risk from Anti-Biofouling Coatings of MHK Devices}

Little is known about the potential for adverse effects on the aquatic environment from the development of renewable ocean energy, leading to regulatory and stakeholder concerns and subsequent delays in deploying systems. One concern associated with MHK deployment is the potential for the antifouling coatings used on the devices to affect water quality. To address this concern, PNNL conducted a screening-level risk assessment that estimated the increase in ambient sediment and water concentrations of antifouling compounds potentially resulting from MHK device deployment and compared the concentrations to existing regulatory or conservative toxicological benchmarks intended to be protective of aquatic life.

This screening-level risk assessment follows the well-established process of hazard definition, exposure assessment, effects assessment, and risk characterization (NRC 1983). Hazard definition consists of a description of the anticipated and/or potential environmental release, the valued environmental attributes and/or regulatory standards that would need to be protected or met, and the environmental context in which both would occur. In the current instance, the release consists of the slow release of antifouling biocides from MHK devices emplaced in surface waters of estuaries and coasts. For the screening-level assessment, we focused on those biocides that are most commonly used for MHK applications planned in the United States, namely copper and zinc, with Irgarol 1051 and Diuron as booster biocides. The valued environmental attributes and regulatory thresholds used as screening levels were water and sediment quality criteria, where available, and chronic low-/no-effect benchmarks that are below $90 \%$ of reported effects levels.

\footnotetext{
${ }^{1} \mathrm{http}: / /$ sustainablebusinessoregon.com, 7 November 2011.

2 http://oregonwave.org, 1 December 2011.

3 http://Aquamarinepower.com.
} 
Two case studies were included in the assessment: the SnoPUD tidal turbine energy project in Admiralty Inlet, Puget Sound, Washington, and the OPT wave buoy project at Reedsport, Oregon. Because these case studies include two different types of MHK devices deployed in estuary and ocean environmental settings, they provide a representative overview of the potential effects of anti-biofouling coatings on aquatic resources.

The full analysis for toxicity of anti-biofouling coatings is documented in PNNL-21260, Assessment of Toxicity to Aquatic Resources from Antifouling Coatings Used on Marine and Hydrokinetic Devices (Brandt et al. 2012).

\subsubsection{Case Study: Tidal Power in Admiralty Inlet, Washington}

SnoPUD is proceeding with plans to install two OpenHydro 6-m tidal energy devices (from OpenHydro) in Admiralty Inlet, located in Puget Sound, Washington (SnoPUD 2010). OpenHydro is currently planning to use Trilux 33 from Akzo Nobel's Interlux line as an antifouling coating. This coating relies on a copper-zinc mixture to provide biocide function and does not contain an organic booster biocide. However, to make the results more widely applicable, the screening assessment addressed formulations of antifouling coatings that contain organic biocides, placed in the Admiralty Inlet environment.

For this screening-level risk assessment, the local water body was defined as the Admiralty Inlet area, which is connected to the main basin of Puget Sound and the Strait of Juan de Fuca. Key parameters for these water bodies are shown in Table 1. By applying environmental transport model parameters and taking into account the high tidal flows within Admiralty Inlet, PNNL determined that sediment accumulation is effectively nonexistent in the main channel of Admiralty Inlet. However, sediments accumulate in lower-flow areas throughout Puget Sound; hence, this screening-level assessment quantified MHK-derived biocide accumulation in sediments within the main basin.

Table 1. Estimates of water volumes, water residence times, sedimentation rates, and sediment area for the Admiralty Inlet case study (Lavelle et al. 1985; Babson et al. 2006; Pelletier and Mohamedali 2009; Brandenberger et al. 2011).

\begin{tabular}{lcccc}
\hline Location & $\begin{array}{c}\text { Sediment Area } \\
\left(10^{8} \mathrm{~m}^{2}\right)\end{array}$ & $\begin{array}{c}\text { Sedimentation Rate } \\
\left(\mathrm{g} \mathrm{cm}^{-1} \mathrm{y}^{-1}\right)\end{array}$ & $\begin{array}{c}\text { Total Water Volume } \\
\left(10^{13} \mathrm{~L}\right)\end{array}$ & $\begin{array}{c}\text { Residence Time } \\
(\mathrm{d})\end{array}$ \\
\hline Admiralty Inlet & 0 (high current) & 0 (high current $)$ & 3.41 & 14.1 \\
Main Basin & 5.83 & $0.87(0.26-1.58)$ & 6.48 & 31.5 \\
\hline
\end{tabular}

The turbine and cowling surface area of the two OpenHydro devices that will be coated with antifouling material will be on the order of $450 \mathrm{~m}^{2}$.

Concentrations of copper and zinc have been monitored throughout the Puget Sound region in both sediment and water. Concentrations of copper in seawater range from 0.26 to $2.76 \mu \mathrm{g} / \mathrm{L}$, averaging $0.5125 \mu \mathrm{g} / \mathrm{L}$ (Table 2). 
Table 2. Reported concentrations of copper and zinc in Puget Sound water and sediments.

\begin{tabular}{lcc}
\hline & $\begin{array}{c}\text { Seawater }(\mathrm{ng} / \mathrm{L}), \\
\min -\max (\text { mean })\end{array}$ & $\begin{array}{c}\text { Sediment }(\mathrm{mg} / \mathrm{kg}), \\
\min -\max (\mathrm{mean})\end{array}$ \\
\hline Copper & $260-2,760(512.5)$ & $0.1-8,900(42.3)$ \\
Zinc & $360-7,280(920)$ & $1-463(70)$ \\
\hline
\end{tabular}

The results of the screening-level assessment for the Admiralty Inlet case study are shown in Table 3 . Biocide risks to aquatic biota are far below levels of potential concern; in this case study, MHK devices contribute less than 1 part in 1000 to the overall risk profile from all sources of biocides in the Puget Sound environment. In the case of the organic booster biocides, the hazard quotients derived from using toxicological benchmarks are not raised to levels of concern, even when the lowest levels identified by others referenced earlier are used. As a guideline, hazard quotients less than 1 indicate that the concentration will not be expected to cause adverse health effects.

Copper and zinc contributions from MHK devices will not lead to exceedances of Washington State's Sediment Quality Standards or the EPA water quality standards. The contribution of these devices to local water and sediment concentrations would be between 1 part per billion and 10 parts per trillion for either metal in sediment or water.

Table 3. Results of screening-level risk assessment for Admiralty Inlet case study.

\begin{tabular}{lcccc}
\hline & Copper & Zinc & Diuron & Irgarol \\
\hline MHK-derived water concentration (ng/L) & $1.11 \mathrm{E}-05$ & $5.52 \mathrm{E}-06$ & $9.41 \mathrm{E}-27$ & $1.89 \mathrm{E}-27$ \\
MHK-derived sediment concentration (ng/kg) & $1.76 \mathrm{E}-01$ & $6.95 \mathrm{E}-02$ & $2.41 \mathrm{E}-25$ & $1.37 \mathrm{E}-25$ \\
Background water concentration $(\mathrm{ng} / \mathrm{L})$ & $5.13 \mathrm{E}+02$ & $9.62 \mathrm{E}+02$ & $1.04 \mathrm{E}-23$ & $2.08 \mathrm{E}-24$ \\
Background sediment concentration (ng/L) & $4.23 \mathrm{E}+07$ & $7.00 \mathrm{E}+07$ & $2.66 \mathrm{E}-22$ & $1.50 \mathrm{E}-22$ \\
Total water concentration (ng/L) & $5.13 \mathrm{E}+02$ & $9.62 \mathrm{E}+02$ & $1.04 \mathrm{E}-23$ & $2.08 \mathrm{E}-24$ \\
Water (chronic) benchmarks (ng/L) & $3.10 \mathrm{E}+03$ & $1.20 \mathrm{E}+05$ & $3.00 \mathrm{E}+02$ & $6.20 \mathrm{E}+01$ \\
Total sediment concentration (ng/kg) & $4.23 \mathrm{E}+07$ & $7.00 \mathrm{E}+07$ & $2.66 \mathrm{E}-22$ & $1.50 \mathrm{E}-22$ \\
Sediment (chronic) benchmarks (ng/kg) & $3.90 \mathrm{E}+08$ & $4.10 \mathrm{E}+08$ & $5.63 \mathrm{E}+03$ & $3.36 \mathrm{E}+03$ \\
$\begin{array}{l}\text { Hazard quotient for water (total water } \\
\text { concentration/benchmark) }\end{array}$ & $1.65 \mathrm{E}-01$ & $8.02 \mathrm{E}-03$ & $3.46 \mathrm{E}-26$ & $3.35 \mathrm{E}-26$ \\
$\begin{array}{l}\text { Hazard quotient for sediment (total sediment } \\
\text { concentration/benchmark) }\end{array}$ & $1.08 \mathrm{E}-01$ & $1.71 \mathrm{E}-01$ & $4.72 \mathrm{E}-26$ & $4.48 \mathrm{E}-26$ \\
\hline
\end{tabular}

(a) Hazard quotient values were determined based on chronic benchmarks. 


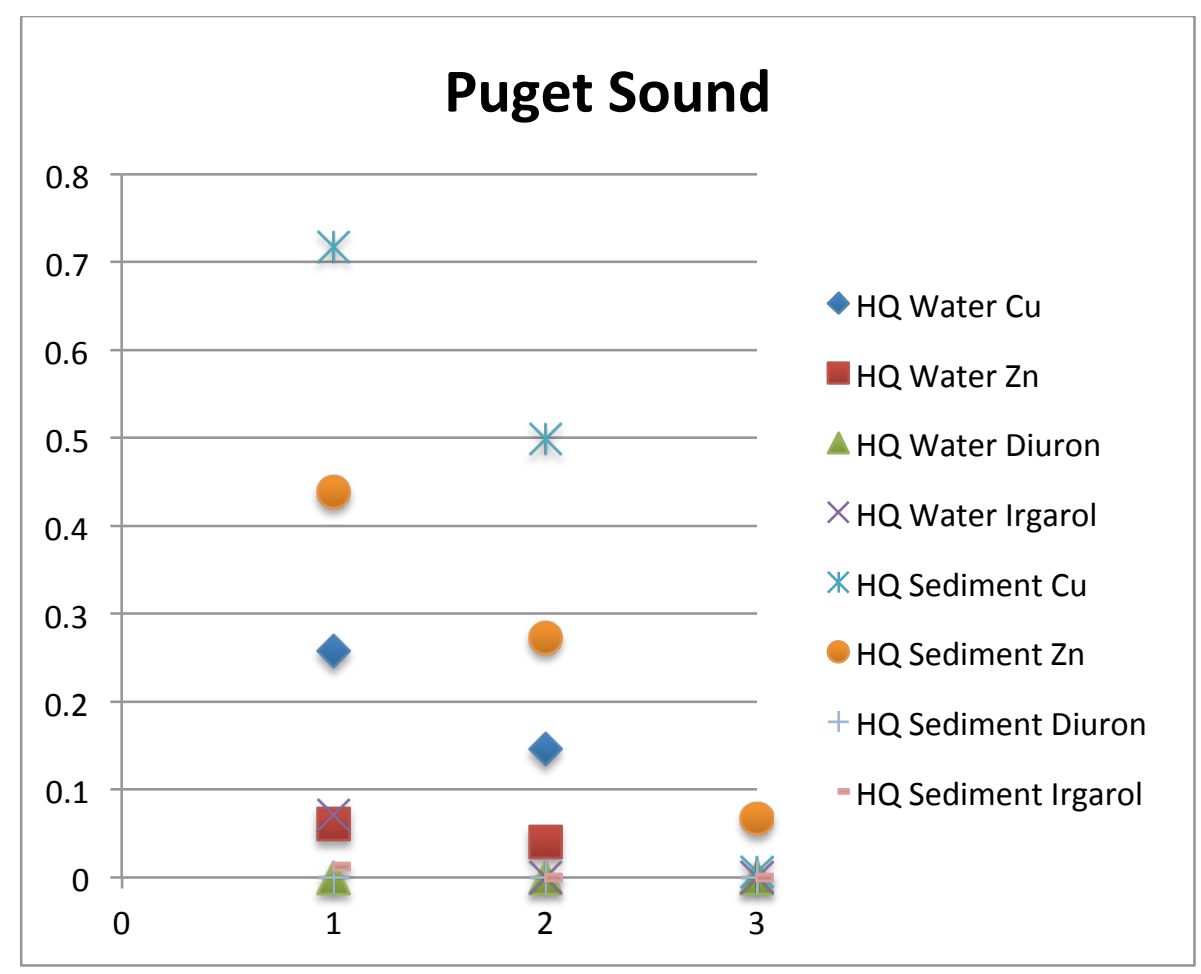

Figure 2. Hazard quotients (HQ) for maximum (1), mean (2), and minimum (3) toxicological benchmarks and exposure parameters for Puget Sound case study.

\subsubsection{Case Study: Wave Power at Reedsport, Oregon}

Wave power devices from Ocean Power Technologies (OPT) are planned for deployment $4 \mathrm{~km}$ (2.5 nautical mi) off the coast from the Oregon Dunes National Recreation Area near Reedsport, Oregon (Figure 6; PNNL 2012b). The planned deployment would consist of 10 Model PB150 PowerBuoys, each with a $150-\mathrm{kW}$ capacity. These devices have a $3-\mathrm{m} \times 11-\mathrm{m}$-diameter float riding on a shaft approximately $25 \mathrm{~m}$ long by $3 \mathrm{~m}$ in diameter (OPT 2010). They would be anchored by 16 subsurface floats; electrical power will be routed through a single underwater substation pod. All of these devices are currently planned to be coated using Ameron ABC \#3 antifouling paint. This paint consists of a copper-zinc oxide formula that together comprises $70 \%$ of the mass of the paint (EPA 2003). This paint does not contain an organic booster biocide.

The deployment area would cover an area approximately $0.25 \mathrm{mi}^{2}\left(6.4 \mathrm{E} 5 \mathrm{~m}^{2}\right)$, with a depth varying between 50 and $69 \mathrm{~m}$ (OPT 2010). Primary currents in the area are long-shore, averaging approximately $20 \mathrm{~cm} / \mathrm{s}$, based on COAST monitoring data ${ }^{1}$ and Karp-Boss et al. (2004). Bottom sediments are characterized as medium to fine sand (OSU Sea Grant 1972; USACE 1989; OPT 2010), with an average total organic carbon content of $0.64 \%$ (CEMAP 2003) and a typical wet bulk density of $1,400 \mathrm{~kg} / \mathrm{m}^{3}$ (Wolf et al. 1999). Reported concentrations of suspended particulate matter in the coastal waters of Oregon range from $250 \mu \mathrm{g} / \mathrm{L}$ to 14,000 $\mu \mathrm{g} / \mathrm{L}$ (Kitchen et al. 1978; Bishop 1986; CEMAP 2003; Karp-

\footnotetext{
${ }^{1} \mathrm{http}: / /$ www.oceanpowertechnologies.com/coos.html.
} 
Boss et al. 2004), averaging 7,700 $\mu \mathrm{g} / \mathrm{L}$, with an average fractional organic carbon content of 0.2 (Hobson 1967). Together, these were used to produce the site-specific transport parameters for the screening exposure model.

Background concentrations of copper and zinc have been measured in sediment at a number of coastal locations in Oregon waters. ${ }^{1}$ Measurements of these constituents in water, however, are not available. Nearest available measurements are from Washington coastal waters. ${ }^{2}$ In lieu of site-specific data, the Washington coastal data were employed for Reedsport (Table 4).

Table 4. Background concentrations of copper and zinc in Oregon coastal sediments and Washington coastal waters [min - max (average)].

\begin{tabular}{lcc}
\hline & Seawater (ng/L) & Sediment $(\mathrm{mg} / \mathrm{kg})$ \\
min-max $($ mean $)$ & min-max $($ mean) \\
\hline Copper & $281-1,470(642)$ & $2-78.9(16.4)$ \\
Zinc & $360-2,040(690)$ & $5-129(55)$ \\
\hline
\end{tabular}

Background concentration measurements for Diuron and Irgarol do not exist for the Reedsport area or anywhere within Oregon coastal waters. Consequently, background concentrations for these organic biocides were estimated following the method described for the Puget Sound scenario. In this open ocean case, we assumed that the background source term (marine vessels) was $10 \%$ of that in Puget Sound.

The results of the screening-level assessment for the Reedsport case study are shown in Table 5. Biocide risks to aquatic biota are below levels of potential concern, with MHK devices contributing less than 1 part per million to background risks from copper and zinc, which are the only two biocides planned for use in the current scenario. Should organic booster biocides be envisioned for use at this site, the risks would be in the parts-per-million level.

Table 5. Results of screening-level risk assessment for Reedsport case study.

\begin{tabular}{lcccc}
\hline & Copper & Zinc & Diuron & Irgarol \\
\hline MHK-derived water concentration $(\mathrm{ng} / \mathrm{L})$ & $2.57 \mathrm{E}-02$ & $1.27 \mathrm{E}-02$ & $5.41 \mathrm{E}-02$ & $8.33 \mathrm{E}-02$ \\
MHK-derived sediment concentration $(\mathrm{ng} / \mathrm{kg})$ & $4.08 \mathrm{E}+02$ & $1.60 \mathrm{E}+02$ & $5.55 \mathrm{E}+00$ & $2.41 \mathrm{E}+01$ \\
Background water concentration $(\mathrm{ng} / \mathrm{L})$ & $6.42 \mathrm{E}+02$ & $6.90 \mathrm{E}+02$ & $2.09 \mathrm{E}-23$ & $4.19 \mathrm{E}-24$ \\
Background sediment concentration $(\mathrm{ng} / \mathrm{L})$ & $1.71 \mathrm{E}+07$ & $5.50 \mathrm{E}+07$ & $2.14 \mathrm{E}-21$ & $1.21 \mathrm{E}-21$ \\
Total water concentration $(\mathrm{ng} / \mathrm{L})$ & $6.42 \mathrm{E}+02$ & $6.90 \mathrm{E}+02$ & $5.41 \mathrm{E}-02$ & $8.33 \mathrm{E}-02$ \\
Water (chronic) benchmarks $(\mathrm{ng} / \mathrm{L})$ & $3.10 \mathrm{E}+03$ & $1.20 \mathrm{E}+05$ & $3.00 \mathrm{E}+02$ & $6.20 \mathrm{E}+01$ \\
Total sediment concentration $(\mathrm{ng} / \mathrm{kg})$ & $1.71 \mathrm{E}+07$ & $5.50 \mathrm{E}+07$ & $5.55 \mathrm{E}+00$ & $2.41 \mathrm{E}+01$ \\
Sediment (chronic) benchmarks $(\mathrm{ng} / \mathrm{kg})$ & $3.90 \mathrm{E}+08$ & $4.10 \mathrm{E}+08$ & $5.63 \mathrm{E}+03$ & $3.36 \mathrm{E}+03$ \\
Hazard quotient - water (total water & $2.07 \mathrm{E}-01$ & $5.75 \mathrm{E}-03$ & $1.80 \mathrm{E}-04$ & $1.34 \mathrm{E}-03$ \\
concentration/benchmark) & & & & \\
Hazard quotient - sediment (total sediment & $4.38 \mathrm{E}-02$ & $1.34 \mathrm{E}-01$ & $9.86 \mathrm{E}-04$ & $7.16 \mathrm{E}-03$ \\
concentration/benchmark) & & & & \\
\hline
\end{tabular}

(a) Chronic benchmarks were used in computing the hazard quotients.

${ }^{1}$ Data from Oregon Department of Environmental Quality's Laboratory Analytical Storage and Retrieval (LASAR) database, available from http://deq12.deq.state.or.us/lasar2/ and CEMAP (2003).

${ }^{2}$ Data compiled from the Washington Department of Ecology Environmental Information Management Database,




To assess the influence of uncertainty on these results, the analysis was done using maximum and minimum values, as well as mean values, for all parameters in Table 5. Maximum, minimum, and mean toxicological reference benchmarks also were used. The results (Figure 3) show that all hazard quotients are all well below 1.0, which indicates the unlikelihood of adverse health effects. Potential MHK emissions contribute less than 10 parts per billion to background concentrations.

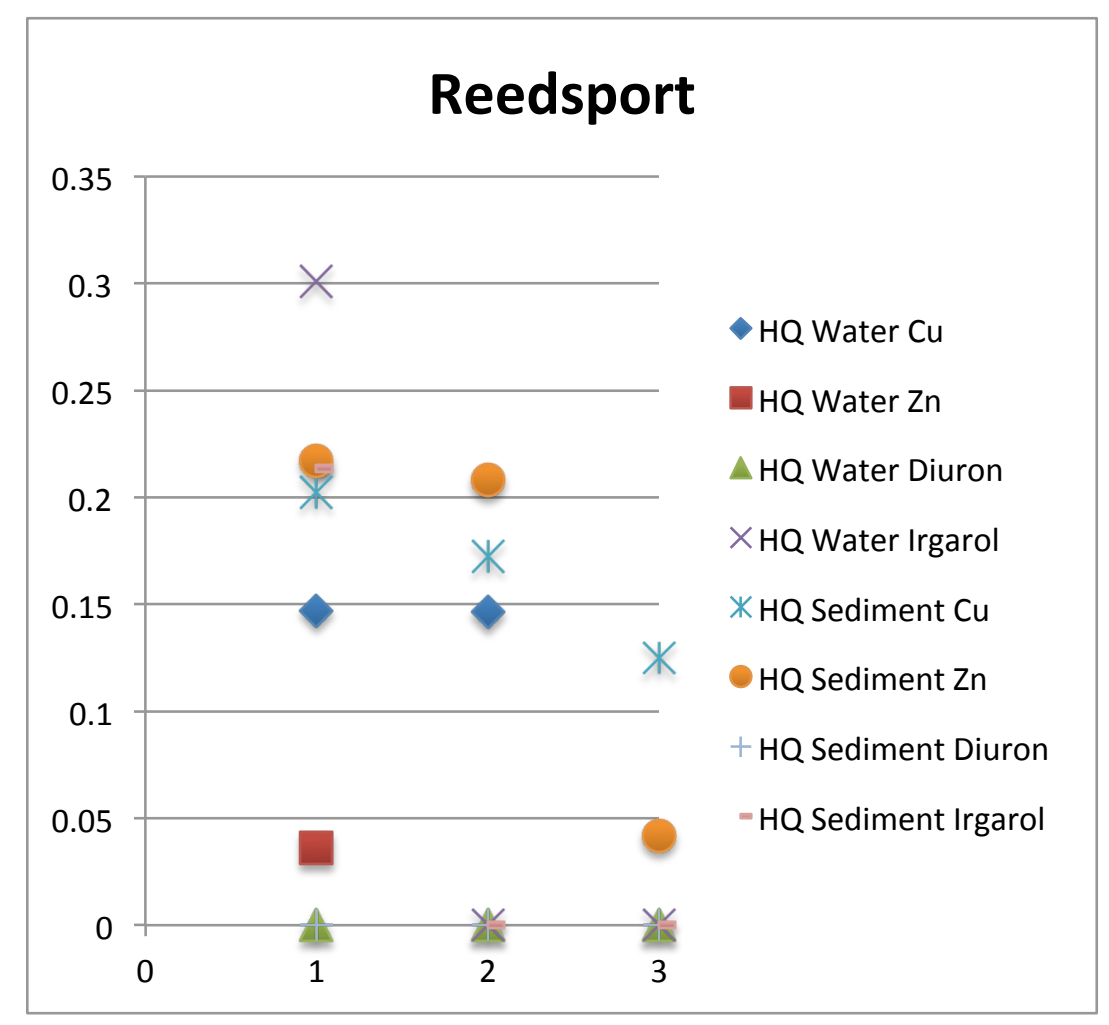

Figure 3. Hazard quotients (HQ) for maximum (1), mean (2), and minimum (3) toxicological benchmarks and exposure parameters for Reedsport case study.

\subsection{Assessment of a Strike of Adult Killer Whales by an OpenHydro Tidal Turbine Blade}

SnoPUD proposes to deploy two OpenHydro tidal turbines in Admiralty Inlet, Puget Sound. The fisheries service of the National Oceanic and Atmospheric Administration (NOAA Fisheries) has expressed concerns that the turbines may cause a risk for the highly endangered SRKW population if a whale were struck by an operating turbine. NOAA Fisheries is responsible for protecting the (fewer than 90) SRKWs under the Endangered Species Act of 1973 and the Marine Mammal Protection Act of 1972. Because the SRKW numbers are so small, significant injury of a single animal could place the population in jeopardy.

PNNL and SNL were tasked by DOE EERE to carry out an analysis of the mechanics and biological consequences of strike of a SRKW by an OpenHydro turbine blade. The approach taken by the two laboratories was to 1) develop a scenario for the most severe strike of a SRKW; 2) determine the morphological and biomechanical properties of SRKW tissues that might be affected by a strike; 3) model the forces of a strike; 4) estimate the potential effects on SRKW tissue and bone of a strike; and 5) 
provide some validation for the model through literature review and discussion with marine veterinarians responsible for marine mammal welfare.

Full details of the assessment can be found in PNNL-21177, Assessment of Strike of Adult Killer Whales by an OpenHydro Tidal Turbine Blade (Carlson et al. 2012).

\subsubsection{Risk of Encounter Between OpenHydro Tidal Turbine Blade and Killer Whale}

PNNL and SNL developed a worst-case exposure scenario for strike of a SRKW. SNL modeled a turbine blade (based on proprietary design data obtained from OpenHydro) and calculated the force of blade impact on the head of an adult male SRKW weighing approximately $4000 \mathrm{~kg}$. The adult SRKW was selected for the model because an adult has a large body mass where more of the energy in a blade strike will be absorbed by the whale's tissue rather than going into momentum transfer that would push the whale out of the path of the turbine blade. This scenario would maximize the risk of injury to the SRKW. Although a juvenile SRKW might intuitively be considered to be at greater risk of injury, because of its much smaller mass $(\sim 500 \mathrm{~kg})$ more of the energy in the blade strike would go into momentum transfer, pushing the juvenile SRKW out of the path of the turbine's blades, leaving much less available to damage tissue.

Recent NOAA publications provided appropriate SRKW swimming speeds of $1 \mathrm{~m} / \mathrm{sec}$ to $3 \mathrm{~m} / \mathrm{sec}$ for the type of encounter envisioned in this scenario. The modeling results showed maximum stresses (pressure) for turbine blade strike of the head of an adult male SRKW to vary between 2350 and 2365 $\mathrm{kPa}$, with strains (tissue elongation) of $73-93 \%$ for the most probable rotation speed of the turbine.

PNNL obtained data for the morphology and anatomy from computed tomography (CT) scans of the head of an adult SRKW that died in 2002. Information on the biomechanical properties of whale tissues was found in the scientific literature. The tissues examined included the skin of the whale, other soft tissue, and mandibular bone. Very little is known about the biomechanical properties of whale tissue, particularly the skin, which functions to resist mechanical and other damage and to spread the force of an impact across a region that minimizes the forces acting on underlying tissues. For this analysis, several natural and synthetic rubber material properties were considered as surrogates for SRKW skin.

Comparison of the maximum force acting on soft tissue and bone, estimated by SNL using the finite element models of the turbine blade and whale, with the tissue biomechanics data developed by PNNL provided the basis for assessment of probable injury to SRKW. The analysis found that the maximum levels of stress acting on whale tissue and bone corresponded to tissue response (strain) in the elastic range where whale tissue would be expected to return to its normal shape when the force of the turbine blade was removed without causing permanent change to the tissue. In addition the stresses and strains estimated using the blade and whale models were well below the yield strength for similar material, including natural and synthetic rubber and human skin, by a factor of three or more.

PNNL examined the available literature on blunt force head trauma in marine mammals and interacted with marine veterinarians with experience in caring for injured animals and performing necropsies on animals found dead. 
The results of these analyses provide the following insights into the potential risk of encounter to a SRKW with an OpenHydro tidal turbine in Admiralty Inlet:

- PNNL/SNL analyses determined that a SRKW is not likely to experience significant tissue injury from impact by an OpenHydro turbine blade.

- If whale skin behaves similarly to the materials considered as surrogates for the upper dermal layers of whale skin, it is expected that in the case of a strike, whale skin tissue and the underlying soft tissue would deform, absorb the force of the strike, and return to normal condition after the pressure was removed. These data indicate that the skin would not be torn by blade strike. Using limited data on the strike pressure needed to fracture the mandibular bone (jawbone) of a North Atlantic Right Whale, and assuming the SRKW mandibles have similar biomechanical properties to those of Right Whales, the highest stress predicted by the model (about $3750 \mathrm{kPa}$ ) is highly unlikely to result in the fracture of a SRKW mandible. The available literature and best professional judgment of marine veterinarians did not significantly inform the outcome of the analyses.

There are a number of areas where the PNNL/SNL analysis could not provide insight:

- PNNL/SNL analyses could not provide insight into the potential for subtler changes to SRKWs from an encounter with the turbine, such as changes in behavior

- PNNL/SNL analyses do not adequately inform turbine interactions for other whales with other turbines.

The overall uncertainty of the engineering and biomechanical analyses can best be estimated by assessing the accuracy of each piece of information that informed the analyses. The modeling techniques used are well documented and are unlikely to have introduced significant uncertainty. Table 6 summarizes the uncertainty of each specific information source.

Table 6. Level of certainty associated with each input to the engineering and biomechanical analyses.

\begin{tabular}{|c|c|c|c|}
\hline $\begin{array}{l}\text { Portion of } \\
\text { Analysis }\end{array}$ & $\begin{array}{l}\text { Specific Input to } \\
\text { Analysis }\end{array}$ & $\begin{array}{l}\text { Accuracy/Level } \\
\text { of Certainty of } \\
\text { Information }\end{array}$ & Explanation \\
\hline \multirow[t]{4}{*}{$\begin{array}{l}\text { Modeling of } \\
\text { Strike Forces }\end{array}$} & $\begin{array}{l}\text { Geometry of SRKW } \\
\text { approach to turbine }\end{array}$ & High & $\begin{array}{l}\text { Geometry of turbine based on detailed drawings } \\
\text { from turbine manufacturer; geometry of SRKW } \\
\text { based on reports for several SRKWs studied. } \\
\text { Chose "worst case for injury" approach of SRKW } \\
\text { swimming directly into outer edge of turbine. }\end{array}$ \\
\hline & $\begin{array}{l}\text { Speed and forces } \\
\text { modeled for turbine, as } \\
\text { they vary with tidal } \\
\text { current speed }\end{array}$ & High & $\begin{array}{l}\text { Turbine speeds and tidal current values are well } \\
\text { known, supplied from manufacturer; multiple } \\
\text { model runs to determine forces. }\end{array}$ \\
\hline & $\begin{array}{l}\text { Orientation of animal } \\
\text { with turbine blade, } \\
\text { transfer of momentum }\end{array}$ & Medium & $\begin{array}{l}\text { Limited model runs for orientation of animal, to } \\
\text { ensure choice of "worst case for injury" scenario. } \\
\text { Based on engineering judgment. }\end{array}$ \\
\hline & $\begin{array}{l}\text { Non-linear model for } \\
\text { materials }\end{array}$ & Medium & $\begin{array}{l}\text { Does not include model for dermal layers } \\
\text { (modeled all-blubber whale) or non-linear model } \\
\text { for any materials, leading to overestimate of } \\
\text { potential harm to SRKW from turbine. }\end{array}$ \\
\hline
\end{tabular}




\begin{tabular}{|c|c|c|c|}
\hline \multirow[t]{5}{*}{$\begin{array}{l}\text { Biomechanics of } \\
\text { orca tissues }\end{array}$} & $\begin{array}{l}\text { Information on tissue } \\
\text { thickness and properties } \\
\text { of skin }\end{array}$ & Medium & $\begin{array}{l}\text { No direct measures for head of SRKW; } \\
\text { information adapted from CT scans of SRKW and } \\
\text { literature on other species. Based on professional } \\
\text { judgment. }\end{array}$ \\
\hline & $\begin{array}{l}\text { Information on tissue } \\
\text { thickness and properties } \\
\text { of blubber }\end{array}$ & High & $\begin{array}{l}\text { Good biomechanical property values from } \\
\text { literature to estimate deformation of blubber and } \\
\text { transfer of force to underlying tissue and bone. }\end{array}$ \\
\hline & $\begin{array}{l}\text { Information on tissue } \\
\text { thickness and properties } \\
\text { of bone }\end{array}$ & Medium & $\begin{array}{l}\text { Biomechanics of impact on bone well understood; } \\
\text { used other species in absence of information on } \\
\text { SRKW. Based on professional judgment. }\end{array}$ \\
\hline & $\begin{array}{l}\text { Information on tissue } \\
\text { thickness and properties } \\
\text { of mellon }\end{array}$ & Low & $\begin{array}{l}\text { Tissue thickness from CT scan and necropsy data, } \\
\text { biomechanical values from literature. Properties } \\
\text { from blubber used in model because of similar } \\
\text { biomechanical properties. }\end{array}$ \\
\hline & $\begin{array}{l}\text { Effects of blunt force } \\
\text { trauma }\end{array}$ & Medium & $\begin{array}{l}\text { Good understanding and copious literature for } \\
\text { humans and livestock; little information for } \\
\text { marine mammals. Some anecdotal information } \\
\text { may be gleaned from interviews. Based on } \\
\text { professional judgment. }\end{array}$ \\
\hline $\begin{array}{l}\text { Sensory } \\
\text { response to } \\
\text { impact }\end{array}$ & $\begin{array}{l}\text { Post-trauma effects on } \\
\text { SRKW }\end{array}$ & Low & $\begin{array}{l}\text { No literature on effects. Potential for anecdotal } \\
\text { information from interviews. Not used in model. }\end{array}$ \\
\hline
\end{tabular}

The PNNL/SNL analyses were limited by the available time frame in which results were needed and focused on the mechanical response of whale tissues and bone to blade strike. Additional information on the biomechanical properties of marine mammal tissues and finite model refinements could help to further fine-tune this analysis. This analysis concentrated on the open center design specific to the OpenHydro turbine; the results may not be directly comparable to other turbine designs.

\subsection{Discussion/Conclusion}

With this report, the initial stages of ERES framework development are completed. Until there are many more data available to replace the professional judgment used to rank consequences of S-R interactions for specific cases, the focus in risk assessment for MHK development will be on determining risk for specific interactions. The toxicity screening analysis and SRKW strike analyses represent two of these interactions.

\subsection{Screening Analysis for Tidal and Wave Case Studies}

The screening analysis for risk associated with developing MHK projects can be separated into three categories: environmental risk, regulatory risk, and investment risk. Environmental risk can be described as the risk posed by the technology to living organisms and the physical and chemical processes that support living systems. Regulatory risk is the risk to MHK permitting and approvals due to regulations or their implementation. Investment risk is the risk to capital investment due to regulatory, legal, or market forces. The ERES process was created to address environmental risk because environmental risk also 
drives regulatory and investment risk. The ERES wave and tidal case studies illustrate the value of assessing environmental risk to reduce both regulatory and investment risks.

The consequence analysis for the ORPC tidal case study in FY 2011 showed that issues of highest concern included interactions with the dynamic physical presence (i.e., blade strike) with marine mammals, diving birds, and threatened and endangered fish. ORPC worked diligently with federal, state, and local regulators and other stakeholders to develop monitoring and mitigation plans that address each of these interactions of highest concern. The ORPC plans were successfully adopted in a FERC pilot project license in FY 2012. Addressing the issues of high environmental consequence also has mitigated regulatory and investment risks, and the commercial tidal project is moving forward.

The consequence analysis of the Oyster wave energy device on the Oregon coast showed particularly high relative risk to the physical environment, as well as a high relative risk to threatened and endangered species of nearshore marine mammals, birds, reptiles and fish. This level of potential environmental consequences of the new technology contributed to a highly restrictive regulatory climate in the state of Oregon that resulted in a high investment risk and decision by Aquamarine Power to pull out of Oregon in FY 2012. Continued environmental testing of the Oyster wave energy device at EMEC and other project locations in Europe will aid in future development prospects on the U.S. West Coast.

By determining the highest-priority risks for stressors from MHK devices and associated installations with vulnerable receptors in the marine and freshwater environment, the ERES screening process assists project proponents, regulators, and stakeholders engage in the most efficient and effective siting and permitting pathways.

\subsection{Probability Analyses Undertaken in FY 2012}

\subsubsection{Risk of Toxicity from Anti-Biofouling Paints}

Results from this report showed that hazard quotients were well below than 1.0 for all four compounds using the most conservative set of assumptions for the two source water bodies and MHK device configurations reviewed. A hazard quotient less than 0.1 implies no risk and between 0.1-1.0 the risk is very low. As such, it is unlikely that adverse effects to aquatic biota will be caused from the antifouling coatings on MHK devices. If source water body characteristics, biocide choice or composition, background chemical concentrations, or other model parameters for a proposed project differ substantially from those described above, additional risk characterization may be needed. As MHK projects expand to commercial scale, providing increased surface area protected by anti-biofouling coatings, additional modeling may be necessary to determine the potential increased risk of toxicity to aquatic organisms.

\subsubsection{Assessment of Encounter Between OpenHydro Tidal Turbine Blades and Southern Resident Killer Whales}

The engineering and biomechanical analyses conducted for this study indicate that insight can be provided into potential interactions between marine animals and turbines. However, it is clear that the information base of biomechanical properties for marine mammal tissues lacks key pieces critical to the analyses. To account for the lack of data, conservative estimates were made, and the worst-case scenario 
was used for the modeling studies. Though our conservative estimates showed little risk, we propose the collection of an enhanced database of marine mammal biomaterial properties, since the significant injury of even one SRKW could be consequential to the population. This information could be collected through a coordinated action to recover more biomechanical information on marine mammal tissue and bone as a routine part of the existing necropsies on animals found dead. Also of importance are data on specific properties and operational modes of turbines that could cause harm to marine animals; for example, material properties that can be used on the leading edges of turbine blades to decrease potential harm to animals. Animal models are needed that can connect the biomechanical properties of marine mammals and design criteria for turbines, allowing for a modeling application to evaluate the design of turbines before deployment.

Though the model may help to inform other modeling efforts, it is also important to note that the analyses performed here do not necessarily predict interactions between tidal turbine blades from devices with designs different from those of the open-center OpenHydro turbine, nor are these analytical outcomes necessarily transferable to turbine blade interactions with other marine mammals. Similar forces are likely to be exerted with devices that move at similar speeds, but the shape and orientation of the blades will affect the injuries that the animal may experience. A wider range of turbine designs and marine mammals that encounter them will provide a more complete understanding of the potential consequence of underwater energy devices. We propose that analyses of additional turbine designs, interacting with other marine mammals potentially at risk, be performed. Of particular interest are studies that link turbines with unducted blades and vertical axis turbines with marine mammals that differ in size, body conformation, and mass from the adult SRKWs.

\subsection{References}

Endangered Species Act of 1973. 7 U.S.C. § 136, 16 U.S.C. $§ 1531$.

Marine Mammal Protection Act of 1972. 16 U.S.C. 1361-1407, P.L. 92-522, October 21, 1972, 86 Stat. 1027, as amended by P.L. 94-265, April 13, 1976, 90 Stat. 360; P.L. 95-316, July 10, 1978, 92 Stat. 380; P.L. 97-58, October 9, 1981, 95 Stat. 979; P.L. 98-364, July 17, 1984, 98 Stat. 440; P.L. 99-659, November 14, 1986, 100 Stat. 3706; P.L. 100-711, November 23, 1988, 102 Stat. 4755; P.L. 101-627, November 28, 1990, 100 Stat. 4465; P.L. 102-567, October 29, 1992, 106 Stat. 4284; P.L. 103-238, 3, April 30, 1994, 108 Stat. 532; P.L. 105-18, June 12, 1997, 111 Stat. 187; and P.L. 105-42, August 15, 1997, 111 Stat. 1125.

Anderson RM, AE Copping, and FB Van Cleve. 2010. Preliminary Screening Analysis for the Environmental Risk Evaluation System - Task 2.1.1: Evaluating Effects of Stressors - Fiscal Year 2010 Progress Report. PNNL-19990, Pacific Northwest National Laboratory, Richland, Washington.

Aquamarine Power. 2012. Wave power project in Scotland, Ireland, and the USA. Aquamarine Power Ltd., Edinburgh, Scotland. Available from http://www.aquamarinepower.com/projects/ (September 2012).

Bishop JKB. 1986. The correction and suspended particulate matter calibration of Sea Tech transmissometer data. Deep-Sea Research 33:121-134. 
Brandenberger JM, P Louchouarn, and EA Crecelius. 2011. Natural and post-urbanization signatures of hypoxia in two basins of Puget Sound: Historical reconstruction of redox sensitive metals and organic matter inputs. Aquatic Geochemistry 17:645-670.

Brandt CA, JA Ward, JM Brandenburger, and AE Copping. 2012. Assessment of Toxicity to Aquatic Resources from Antifouling Coatings Used on Marine and Hydrokinetic Devices. PNNL-21260, Pacific Northwest National Laboratory, Richland, Washington.

Campbell-Malone RP. 2007. Biomechanics of North Atlantic Right Whale Bone: Mandibular Fracture as a Fatal Endpoint for Blunt Vessel-Whale Collision Modeling. Massachusetts Institute of Technology, Cambridge,Massachusetts.

Carlson TJ, JL Elster, ME Jones, BE Watson, AE Copping, ML Watkins, RA Jepsen, and K Metzinger. 2012. Assessment of Strike of Adult Killer Whales by an OpenHydro Tidal Turbine Blade. PNNL-21177, Pacific Northwest National Laboratory, Richland, Washington.

CEMAP. 2003. CEMAP Water Quality Sampling June 2003, Sites 30221 and 30242. Coastal Environmental Monitoring and Assessment Program, U.S. Environmental Protection Agency, Washington, D.C. Available from http://deq12.deq.state.or.us/lasar2/SearchLasar.aspx?page=1\&dt=0 (March 2012).

Copping AE, KM Blake, RM Anderson, LC Zdanski, GA Gill, and JA Ward. 2011. Screening Analysis for the Environmental Risk Evaluation System - Task 2.1.1: Evaluating Effects of Stressors - Fiscal Year 2011 Progress Report. PNNL-20805, Pacific Northwest National Laboratory, Richland, Washington.

EPA. 2003. Draft Characterization Report for Hull Coating Leachate. EPA 842-D-06-001, Office of Prevention, Pesticides, and Toxic Substances, U.S. Environmental Protection Agency, Washington, D.C.

EPA. 2011. Integrated Risk Information System (IRIS). U.S. Environmental Protection Agency, Washington, D.C. Available from http://www.epa.gov/iris/index.html (September 2012).

FERC. 2012. Order Issuing Pilot Project License (Minor Project), February 27, 2012. Ocean Renewable Power Company Maine, LLC, Project No. 12711-005. 138 FERC 92,168 , Federal Energy Regulatory Commission, Washington, D.C. Available from http://elibrary.ferc.gov/idmws/

file_list.asp?document_id=13998936 (October 2012).

Friebertshauser MA and AC Duxbury. 1972. Water budget study of Puget Sound and its subregions. Limnology and Oceanography 17:237-247.

Hobson LA. 1967. The seasonal and vertical distribution of suspended particulate matter in an area of the northeast Pacific Ocean. Limnology and Oceanography 12:642-649.

Karp-Boss L, PA Wheeler, B Hales, and P Covert. 2004. Distributions and variability of particulate organic matter in a coastal upwelling system. Journal of Geophysical Research 109:C09010.

Kitchen JC, JRV Zaneveld, and H Pak. 1978. The vertical structure and size distributions of suspended particles off Oregon during the upwelling season. Deep-Sea Research 25:453-468. 
O'Brien L. 2011. State planning process too slow for one wave energy firm. Oregon Wave Energy Trust (OWET), 1 Dec. 2011. Available from http://www.oregonwave.org/state-planning-process-too-slow-forone-wave-energy-firm/ (September 2012.

Ocean Power Technologies. 2010. Reedsport OPT Wave Park. FERC Project No 12713. ApplicantPrepared Environmental Assessment, Volume II of IV, Reedsport OPT Wave Park, LLC, Pennington, New Jersey.

OSU Sea Grant. 1972. Continental Shelf Sediments Off Oregon. Commercial Fishing Publication, S.G. Number 8, Marine Advisory Program, Oregon State University Extension Service, Corvallis.

Pelletier G and T Mohamedali. 2009. Control of Toxic Chemicals in Puget Sound: Phase 2, Development of Simple Numerical Models: The Long-Term Fate and Bioaccumulation of Polychlorinated Biphenyls in Puget Sound. 09-03-015, Environmental Assessment Program, Washington State Department of Ecology, Olympia. Available from http://www.ecy.wa.gov/biblio/0903015.html (March 2012).

Portland Press Herald. September 13, 2012. "Maine tidal turbine goes online, first in North America."

PNNL. 2012a. Admiralty Inlet Tidal Energy Project. Pacific Northwest National Laboratory, Richland, Washington. Available from http://mhk.pnnl.gov/wiki/index.php/Admiralty_Inlet_Tidal_Energy_Project (March 2012).

PNNL. 2012b. Reedsport OPT Wave Park. Pacific Northwest National Laboratory, Richland, Washington. Available from http://mhk.pnnl.gov/wiki/index.php/Reedsport_OPT_Wave_Park (March 2012).

Suter, GW. 1993. Ecological Risk Assessment. Lewis Publishers, Boca Raton, Florida.

USACE. 1989. Umpqua Ocean Dredged Material Disposal Site Evaluation. Final Report, U.S. Army Corps of Engineers, Portland District, Portland, Oregon.

Williams C. 2011. Aquamarine Power leaves Oregon citing regulatory uncertainty. Sustainable Business Oregon. Available from http://www.sustainablebusinessoregon.com/articles/2011/11/ aquamarine-power-leaves-oregon-citing.html?page=all (September 2012).

Wolf SC, H Nelson, MR Hamer, G Dunhill, and RL Phillips. 1999. The Washington and Oregon MidShelf Silt Deposit and its Relation to the Late Holocene Columbia River Sediment Budget. Open-File Report 99-173, U.S. Geological Survey, Denver, Colorado. Available from http://geopubs.wr.usgs.gov/open-file/of99-173/of99-173.pdf (March 2012). 


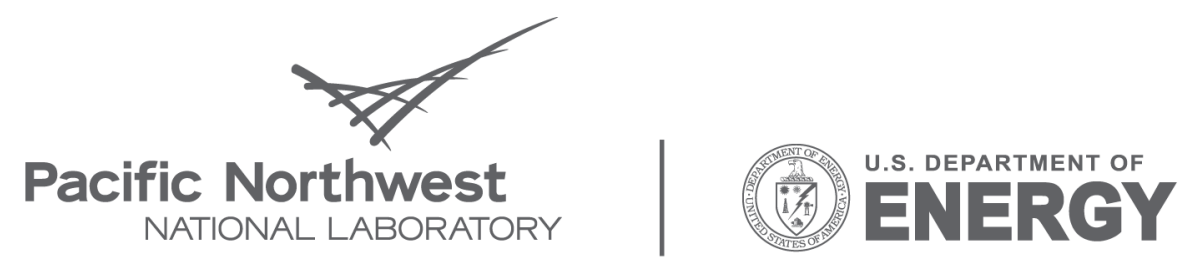

Proudly Operated by Battelle Since 1965

902 Battelle Boulevard

P.O. Box 999

Richland, WA 99352

1-888-375-PNNL (7665)

www.pnl.gov 